\title{
The Role of Customer Innovativeness in the New Products Adoption Intentions: \\ An Empirical Study on Mobile Phone Customers of the Egyptian Universities Students
}

\author{
Hend. S. Hassan ${ }^{1}$ \\ ${ }^{1}$ Faculty of Commerce, Mansoura University, Mansoura, Egypt \\ Correspondence: Hend. S. Hassan, Faculty of Commerce, Mansoura University, Mansoura, Egypt.
}

Received: February 3, 2017

Accepted: March 14, 2017

Online Published: March 23, 2017

doi:10.5539/ibr.v10n4p117

URL: https://doi.org/10.5539/ibr.v10n4p117

\begin{abstract}
This research aims to investigate the relationship between customers' innovativeness and their intentions to adopt new mobile phones from the standpoint of Egyptian university students. The research studies the direct effects of the five dimensions of customers' innovativeness on their intentions of new products adoption, which are measured through the mediating effect of two factors: the risks to mobile phones perceived by the customers and customer involvement. The research also aims to identify the so-called "initiators" segment; customers who have the highest probability for purchase the product early. A quantitative method with deductive approach is chosen in this research. Four hypotheses have been designed to determine: whether there is a significant difference in customers' perception of risks to new mobile phones, innovativeness, involvement, and adoption intentions according to demographic variables (gender, place of residence, income); whether there is a significant positive effect of customers' innovativeness on customers involvements with new mobile phones; whether there is a significant negative effect of customers' innovativeness on the perceived risks to new mobile phones; and whether there is a significant positive effect of customers' innovativeness on their intentions to adopt new mobile phones. A significant impact of the five dimensions of customers' innovativeness is found on the adoption intentions of new mobile phones. Also a significant effect of the five dimensions of customers' innovativeness is found on the perceived risks and customer involvement factors. The research develops a new model of the relationship between the customers' innovativeness and their intentions to adopt new products. In practice, the research results contribute to help marketing managers for better market fragmentation and identify customer segments with high innovativeness; which helps organizations prepare appropriate marketing campaigns and thus leads to the success of new products deployment.
\end{abstract}

Keywords: customer innovativeness, customer involvement, perceived risk, new products adoption intentions

\section{Introduction}

As a result of the tremendous technological progress, products life cycle-has become very short, especially in the technological products. The organizations became obliged to create new products at frequent intervals to meet the requirements of its customers (Hoffmann and Katja 2010). Constant development of new products is a big necessity for the success of any organization and its long-term growth (Shimp, 2000). The introduction of new products to the market also leads to sales growth, market share expansion, increased profitability and stronger competitiveness (Vandecasteele and Maggie, 2009).

Despite the ongoing de velopments in the design and development of new products, most new products fail in an increasing rate (Bartels and Machiel, 2011) noted that the rate of new product failure reached up to $35 \%-45 \%$, while (Wilk and Sorvillo, 2003) pointed that the failure rate in these products may increase up to $80 \%$. Given these high rates, organizations must exploit possible opportunities to maximize potential success, and to avoid losses that may be incurred as a result of the failure (Hoffmann and Katja 2010). Among the opportunities the organizations should exploit is the identification of customers with high potential to buy products early (initiator customers segment). They play an important role in the success of new products. Initiator customers are not price sensitive, always seek information about new products, and have a strong tendencies to modern temptations (Jordaan and Simpson, 2006). 
Unfortunately, initiator customers represent only $2.5 \%$ of the potential market (Hoffmann and Katja, 2010). Thus, the determination of this segment is very difficult, yet important. It represents the most important target group in the deployment of new products, since the use of the new product stimulates other customers to imitate them and buy new products. They also contribute to passing positive word of mouth to other customers.

Based on the above, and given the importance of the role of the customer innovativeness in the success of the deployment of new products, the research proposes a model for the use of the customer innovativeness in the development of the adoption intentions of new products through the mediating effect the two variables, namely: customer - product involvement, and the risks perceived by the customer to the new product.

\section{Exploratory Study}

To clearly articulate the research problem an exploratory study was conducted. It aimed to identify the contemporary intellectual trends in the research relevant fields: customer innovativeness, customer involvement for the product, and the product risks perceived by the customer. The study also aimed to identifying the extent of benefit from these trends in the improvement of the adoption intentions of new products, and to identifying high and low innovative customers and their characteristics. The study was conducted in two phases as follows:

\subsection{Phase 1: Literature Review}

In this stage a number of studies have been reviewed in the research relevant topics: customer inno vativeness, customer involvement for the product, the product risks perceived by the customer, and adoption of new products.

\subsubsection{Customer Innovativeness}

Customer innovativeness is considered one of the most important concepts in customer behaviour area. (Dobre et al., 2009). Studies suggests two types of customer innovativeness, namely: general innovativeness, domain specific innovativeness. (Bartels and Machiel, 2011; Fowler and Eileen, 2010; Im et al., 2007).

General Innovati veness: is a set of personal characteristics of individuals which represent the degree to which the individual can be the first adopters of innovation compared to other members in his social scale (Chao and Mike, 2010). This illustrates that the innovativeness is based on the idea of creativity, which is perceived as an idea or a practice. Innovati veness also represents the degree to which the individual can be more receptive and adoptive to new ideas regardless of the experience of others. From this point of view, general innovativeness affects the adoption intentions of new product from different five characteristics:

1. The need for uniqueness: focuses on the customer early purchase of new products and/or unfamiliar products in his social circle.

2. The need for novelty: focuses on the customer affinity for all that is new of goods and services in order to avoid similarity with others.

3. The need for recognition: focuses on the desire to gain new experiences in line with the mind stimulating objectives.

4. The need for decision making independence: focuses on customer decisions to purchase new products without relying on purchasing experiences of others.

5. The need for functional benefit: focusses on the performance of new products, and product features such as: efficiency, convenience, quality, ease, reliability, more than emotional gratification.

Domain Specific Innovativeness: Narrowing the concerns of customer behaviour in a particular area, which reflect the individual tendencies toward learning and adoption of products within a particular area according to his interests. Studies emphasises that domain specific innovativeness affects the purchase behaviour and the actual use of new products more than the general innovativeness. Also, domain specific innovativeness is used as a measure to recognise the initiator customers who tend to adopt new products (Handa and Gupta, 2009; Klink and Athaide, 2010). All studies use a single scale to measure customer domain specific innovativeness, namely: Goldsmith and Hofacker (1991) scale. It is a validated multi-dimensional scale which consists of six items.

The potential innovators not do foster innovation at the same time. They differ according to their degree of readiness and willingness to try out new innovations (Rogers, 2003). In general, there are five categories of innovators: innovators, early adopters, early majority, late majority, and laggards:

1) Innovators: They account for only $2.5 \%$ of any community. They are willing to take risks, have the highest social status, have financial liquidity, are social and have closest contact to scientific sources and interaction with other innovators. Their risk tolerance allows them to adopt technologies that may ultimately fail. Financial 
resources help absorb these failures.

2) Early Adopters: They account for $13.5 \%$ of the community. They are more integrated into the society. This category includes the vast majority of opinion leaders. They are more discreet in adoption choices than innovators.

3) Early Majority: They represent $34 \%$ of the community; rarely hold positions of opinion leadership in a system. They prefer to wait and adopt an inno vation after a varying degree of time that is significantly longer than the innovators and early adopters. Early Majority have above average social status.

4) Late Majority: They represent $34 \%$ of the community. This category is characterized as being sceptic. They approaches an innovation after the majority of society has adopted it. They adopt innovation because of an economic motive or a social pressure. They deal with innovations with extreme caution.

5) Laggards: Representing $16 \%$ of the community, this category is characterized as being a traditional. They are the last to adopt an innovation. , and typically tend to be focused on "traditions".

\subsubsection{Customer Involvement}

Over the past five decades, customer involvement has received high attention from both scholars and practitioners. It can be considered one of the critical concepts related to purchase decision making process (Jordan and Michelle, 2006) . Involvement can be defined as "a state of motivation, arousal or interest, evoked by a particular stimulus or situation, displaying drive properties" (Ghafelehbashi et al., 2011; Hanzaee et al., 2011) . Customer product involvement is important in understanding consumer attitudes and behaviour because involvement is a central motivating factor that shapes the purchase decision-making process. Involved consumers exhibit feelings of interest, pleasure and enthusiasm towards relevant product categories. Consumers will thus become involved when the object of interest is perceived as important in meeting needs, goals and values (Kim, 2003; Choubtarash,et al., 2013).

Many classifications for customer involvement have been proposed in previous studies. first classification suggested by (Dholakia, 2001, Michaelidou and Dibb, 2008; Huang, 2010) classified involvement into three types: enduring, situational, and response. Enduring Involvement represents the long-term attachment of an individual with a specific product class, which is likely to be manifested through extensive information search, brand knowledge and, eventually through brand commitment. Situational Involvement, however, represents a short-term phenomenon where an individual becomes involved with a 'situation', usually a purchase decision. Response Involvement takes a behavioural view reflecting the extent to which individuals are involved in a situation. This form of involvement refers to a behavioural orientation which involves information acquisition and decision processes. In this context, involvement is seen as behaviour rather than as a mediator of behaviour. The extent of information search and product acquisition time have both been used to conceptualise and measure response involvement. Second classification suggested by (Lin and Chun, 2006 ; Lee, 2005; Ghafelehbashi et al., 2011) grouped involvement into: advertising, purchasing, and product. Advertising Involvement is the customer response after being subjected to the advertisement. This response is based on the customer's interest in the advertisement information. The involvement level ranges from the total focus to the total disregard. Purchasing Involvement refers to the customer's interest in the purchasing process itself. As a result, product information collected during the purchase process increase, as well as the time and effort spent effort and time spent to carry out the purchase. This type of involvement depends on factors related to purchasing situation per se. in other words, purchasing involvement is a situational involvement. Product Involvement is related to the level of a customer's interest in purchasing a certain product type and how committed they are to purchasing a given brand. Product involvement tends to be greater for goods that have a higher cost and are bought after considerable research and thought. Final classification adopted by Lee (2005) grouped involvement into high and low involvement. In general, customers are more involved with high price product with high importance and risk, where customers will be more willing to spend more time and effort to buy these high-involvement products. Vice versa, in case of low-containment products, customers spend less time and effort because of the repeat purchase of these products and low prices and associated risks.

\subsubsection{Perceived Risk}

Perceived risk is a major concept in customer behaviour area. The concept was historically introduced in 1960 and suggested that the customer behaviour include the perceived risk, in the sense that the customer may face a lot of unexpected results after buying the product because some products may not be satisfactory. The concept of perceived risk was apllied in order to examine certain behaviours and concepts such as searching for information, brand loyalty, leadership opinion, reference groups, and repurchase deliberations in the decision-making process 
(Kim, 2003). Perceived risks definition can vary depending on the context (Carroll, 2009). They can be viewed objectively through a quantitative assessment (such as the risk of death resulting from a car accident expressed as a percentage). On the other hand, perceived risks can be viewed personally through customers self-judgment according to their personality and their experience with the product (Slovic and Weber, 2002).Studied have suggested that there are eight effective ways to reduce the perceived risk by customers (Leon et.al 2004), (Ward, 2008) , these are: products information search from official and non-official sources, reference groups' endorsement, brand loyalty, major brand image, store image, seeking reassurance through methods such as money back guarantee and free samples, shopping around and comparing products characteristics in different brands, and finally, buying the expensive model that is usually linked to better quality.

Perceived Risks Dimensions:

Perceived risk is categorized under six dimensions in the previous studies, namely: perceived functional risk; perceived financial risk; perceived physical risk; perceived psychological risk; perceived social risk, and perceived time risks (Bhukya and Singh, 2015). Functional Risk is described in the previous studies (Agarwal and Teas, 2001; Beneke et al., 2012) as the uncertainty that the outcome of a product purchase will not meet consumer expectations. It is also expressed as a performance risk as it demonstrates the consumer's fear that a product will not perform to its promised abilities. Zielke and Dobbelstein (2007) defined Financial Risk as the possibility of a monetary loss from a poor purchase choice/decision. In other words, it is the state of losing money by purchasing an inadequate or unfamiliar brand. This definition can, however, be extended to include the risk that the product's quality does not match its price (Leon et. al, 2004). Physical Risk is defined as the state of the consumer's fear that purchasing certain products may damage their health or physically injure their person. For the instance, it is concerned with purchasing the unfamiliar product that could potentially hurt the consumers (Leon et. al, 2004; Xu, J. et al, 2003). Thus it is concerned with consumer health issues like food poisoning and other food-related diseases. Ueltschy et al. (2004) defined Psychological Risk as the state of consumer's disappointment in making a poor product or service selection and it is related to consumer's discontent with owning or using the product. While switching from national brands to private labels, naturally it causes some form of emotional and psychological pressure due to the uncertainties associated with the new product. Social Risk refers to the possibility that buying a product or using a service can reduce a person's status with friends, family or neighbours. The increasing pace of contemporary life means more customers worry about Time Risks, in particular time lost when a product turns out to need replacement or fails to deliver as promised. It can also include pragmatic concerns about how much time you might spend waiting in line at a crowded retail outlet.

\subsubsection{New Product Innovation}

Innovation is defined as goods, services, ideas or processes perceived by the customer as new things in life. Innovation is concerned with the process of commercialising or extracting value from ideas. This is in contrast with 'invention' which need not be directly associated with commercialisation. (Rogers, 2003). Five features of the new product have been determined. They influence customers to accept or reject new products. These are: relative advantage, compatibility, simplicity/complexity, observability, and trial ability. Relative Advantage refers to the degree to which the customer perceive the difference characteristics of the new product compared to familiar products. Compatibility refers to the appropriateness, consistency and compatibility of the new product and its uses with values, beliefs, habits, and needs of the customer. Simplicity/Complexity refers to the degree of customer perception of the simplicity and ease of use of new product. It is claimed that the customer, who has no previous experience and expertise in the use of some of the innovations of technology, will oppose and resist the adoption of new innovation and will find it difficult to adopt them. Observability refers to the ability to preview innovation by the customer. Trialability refers to the possibility to try new products and verify benefits and evaluate these benefits. Studies such as (Chau and $\mathrm{Hu}, 2001$ ) indicated that there is a positive relationship between the possibility of trying a new product by the customer and its adoption.

Classification of new products is very important when testing the adoption behaviour of customers. The reason is that the type of innovation affects the level of customer or community adoption, and the type of knowledge to be learned for new goods and services. In this view, studies identifies three types of innovation, namely: Continuous Innovation, which refers to slight modification on an existing product instead of creating completely new product; Dynamically Continuous Inno vation ,and it refers to introducing radical changes to the existing product through re-delivering with innovative and important elements; and finally Discontinuous Innovation, which refers to the introduction of a new product in general, which significantly alter consumption patterns and lifestyles. This type of innovation requires a great deal of new learning. 


\subsubsection{New Product Adoption}

New products adoption is one of the important topics for both marketing managers and researchers. It plays an important role in the process of deploying innovations. This urges marketers and researchers need to understand the key determinants of new products adoption, which helps organizations in identifying target market, position their products accurately, and design strategies more effectively (Wang et al., 2008).

The adoption process is complementary to the innovation process. It is called in some studies Actualised Innovativeness. It is defined as "the client's decision to use the product and service systematically and repeatedly". The adoption process for new products varies from one individual to another according to socio economic and demographic characteristics. Five stages have been presented for describing the adoption process:

1. Awareness: customer learns of the idea or practice but has little knowledge about it.

2. Interest: customer develops interest in the idea, seeks more information about it, and consider its general merits.

3. Evaluation: customer makes mental application of the idea, weighs its merits for his own situation,

4. Trial: customer actually applies the idea or practice- usually on a small scale.

5. Adoption: stage of acceptance leading to continued use.

Im et al., (2007) explained that there are three basic ways to determine the new products adoption behaviour. The first method is to determine the relative time the adoptive customers take to own a particular new product compared to others customers. The second method is to identify how many new products owned by the customer from a list prepared in advance of new products.

The final method is to use purchase intentions to predict the adoption behaviour. Several studies has used purchase intentions instead of the actual buying behaviour because the actual purchase behaviour is the inevitable result of the purchase intentions. In the study of Lee (2005), it has been found that $75 \%$ of respondents who purchased the product indicated the possibility and intention of buying it within three to six months. After reviewing several previous studies, it has been found that behavioural intentions are used to measure the new products adoption intensions and therefore, customer innovativeness (Alsaleh, 2010; Hanzaee et al., 2010; huang et al., 2011; Klerck and Sweeney, 2007). Therefore, this method is adopted in this research.

\subsection{Phase 2: Pilot Study}

The pilot study has conducted through an initial survey of a purposive convenient sample of 50 students of the University of Mansoura, to solicit their views on their innovativeness, their perceived risks, and their adoption intentions of the new mobile phones. The sample has been classified into three categories according to innovativeness levels, namely: high innovative customers, medium innovative customers and low innovative customers. Classification was based on the arithmetic mean $(5+1) / 2=3$, and the response format was a 5 Likert point scale ranging from 1 (extremely disagree) to 5 (extremely agree). If the innovati veness degree is higher than the arithmetic mean so it is a high innovative customer. If the innovativeness degree is less than the arithmetic mean, it is low innovative customer, and if the innovativeness degree is equal to the mean, it is a medium innovative customer. The data analysis collected revealed that the number of high innovative customers represented $16 \%$ of the sample, the number of medium innovative customers represented $30 \%$ of the sample, and the number of low innovative customers represented 54\% of the sample. Table (1) below displays average degrees for customer involvement, perceived risks, and the adoption intentions for each category of the three categories of the innovativeness levels.

Table 1. Degrees of customer involvement, perceived risks, and the adoption intentions of new mobile phones for each of the three categories of customer innovativeness

\begin{tabular}{cccc}
\hline Dependant variables & $\begin{array}{c}\text { High Innovative } \\
\text { Customers } \\
(\% 16)\end{array}$ & $\begin{array}{c}\text { Medium Innovative } \\
\text { Customers } \\
(\% 30)\end{array}$ & $\begin{array}{c}\text { Low Innovative Customers } \\
(\% 54)\end{array}$ \\
\hline Customer Involvement & 3.6 & 2.8 & 2.2 \\
Perceived Risks & 2.3 & 2.6 & 3.8 \\
Adoption Intentions & 3.7 & 3.2 & 1.2 \\
\hline
\end{tabular}

The results above shows a presence of high level of customer involvement and adoption intentions in addition to low level of perceived risk to new mobile phones for customers with a high level of innovativeness. While there is an average level of customer involvement and adoption intentions in addition to low level of perceived risk to the new mobile phones for customers with the average level of innovativeness. Finally, there is a low level of customer involvement and adoption intentions in addition to the high level of perceived risk to new mobile 
phones for customers with low level of innovativeness.

\section{Research Gap}

In view of the exploratory study outcomes and reviewing literature, the following research gap have been revealed:

- The absence of studies examining all the variables combined (customer innovativeness, the perceived risk, the customer involvement, and the adoption intentions of new products).

- The absence of studies using customer involvement, and the customer perceived risk as mediating factors in testing the role of the customer's innovativeness in adopting new products.

- The lack of agreement about the nature of the relationship between the variables of the study. This emphasizes that these relations require further study and analysis.

Consequently, the research problem can formulated as follows: The existence of limited adoption intentions of new products by customers with low level of innovativeness and involvement and a high level of perceived risk toward these products, while there is a rise in adoption intentions of new products by customers with a high le vel of innovativeness and involvement and the low level of risk perceived to have towards these products. Therefore, the purpose of this paper is to examine whether there is a significant difference in customers' perception of risks to new mobile phones, innovati veness, involvement, and adoption intentions according to demographic variables (gender, place of residence, income); whether there is a significant positive effect of customers' innovativeness on customers involvements with new mobile phones; whether there is a significant negative effect of customers' innovativeness on the perceived risks to new mobile phones; and whether there is a significant positive effect of customers' innovativeness on their intentions to adopt new mobile phones. The literature review helped to propose a model for the research, shown in Figure 1, which can overcome the research gap found.

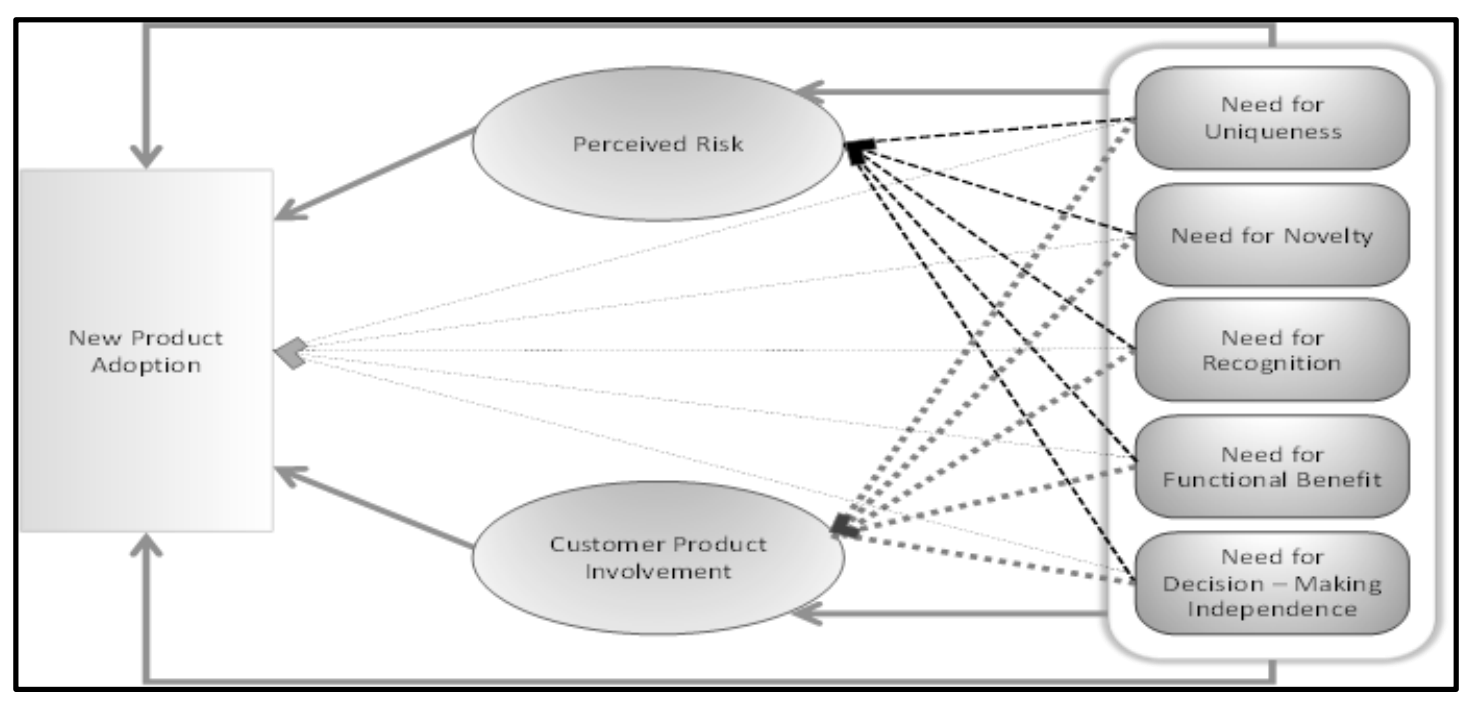

Figure 1. Research proposed model

Four hypotheses have been proposed:

H1: There is a significant difference in customers' perception of risks to new mobile phones, innovativeness, involvement, and adoption intentions according to demographic variables.

H2: There is a significant positive effect of customers' innovativeness on customers' involvements with new mobile phones.

H3: There is a significant negative effect of customers' innovativeness on the perceived risks to new mobile phones.

H4: There is a significant positive effect of customers' innovativeness on their intentions to adopt new mobile phones.

\section{Methodology}

\subsection{Sample}

The population of the study has been determined to be among the students of the public universities in Egypt to examine the above hypotheses. Due to the geographical and economic variation of mobile phone customers and 
the difficulty of covering all Egyptian universities, research sample has been chosen from five governmental universities, by selecting the major university in every main region of the Arab Republic of Egypt. Cairo University has been chosen to represent the Greater Cairo; Alexandria University to represent North coast region, Mansoura University to represent the Delta region, the University of the Suez Canal to represent the Suez Canal region, and the University of Assiut to represent Upper Egypt region. Questionnaires were distributed to 384 students using the stratified sampling technique among the five universities. A total of 318 correct questionnaire were received with a response rate of $(83 \%)$, as shown in table 2 .

Table 2. Sample distribution and response rate

\begin{tabular}{cccc}
\hline University & Sample Size & Response & Response rate \\
\hline Cairo & 130 & 110 & $\% 85$ \\
Alexandria & 98 & 80 & $\% 82$ \\
Mansoura & 85 & 74 & $\% 87$ \\
Assiut & 50 & 36 & $\% 72$ \\
Suez Canal & 21 & 18 & $\% 86$ \\
Total & 384 & 318 & $\% 83$ \\
\hline
\end{tabular}

4.2 The Instrument

A single questionnaire has been designed and directed to mobile phones' customers among public universities' students. The questionnaire consists of four main variables, namely: customer innovativeness, customer involvement, perceived risks, and new product adoption intentions. Each variable has been measured using a number of statements. The response format was a 5- likert point scale ranging from 1 (extremely disagree) to 5 (extremely agree). With a total of 49 statements (items), 21 items have been proposed to measure the five dimensions of customer innovativeness: the need for uniqueness, the need for novelty, the need for recognition, the need for decision making independence, and the need for functional benefit. In addition, 15 items have been used to measure the six dimensions of customer perceived risks to new products: functional risk, financial risk, physical risk, psychological risk, social risk, and time risks. Six items have been used to measure customer involvement, and seven items for customer adoption intentions for buying ne w mobile phones. The questionnaire has been formed using different scales of (Knight and Eun, 2007; Vandecasteele and Maggie, 2010; Kim, 2008; Carroll, 2009; Alsaleh, 2010; Hanzaee et al., 2010; Huang et al., 2011; Klerck and Sweeney, 2007).

\subsection{Reliability and Validity}

After completing the initial questionnaire design, validity test has been conducted to ensure the questionnaire items measures what they are supposed to measure, and they give respondents the meanings intended. For this purpose, the initial questionnaire has been revised by some colleagues, who had some remarks, which have been taken into consideration. Afterwards, the questionnaire has been checked by some university students to verify the phrases wording. Accordingly, some items have been modified, some have been entirely deleted. The reliability of the data has been verified using Cronbach's alpha. Coefficients for this research were all above 0.79 and were concluded to be reliable (Hair et al., 2006). Table 3 below shows reliability test results for research variables using Cronbach's alpha.

Table 3. Cronbach's alpha coefficient for research variables

\begin{tabular}{ccc}
\hline Research variables & Number of scale items & Alpha coefficient \\
\hline Customer Innovativeness & $\mathbf{2 1}$ & $\mathbf{8 2} \%$ \\
Customer Involvement & 6 & $79 \%$ \\
Perceived Risks & 15 & $83 \%$ \\
Adoption Intensions & 7 & $81 \%$ \\
\hline
\end{tabular}

\section{Discussion and Results}

\subsection{Descriptive Data Analysis}

The Arithmetic Average method is used to identify customer innovativeness categories. This is done by calculating the composite mean score for Likert- scale items. Because there are 5 categories in the scale, intervals length equals $4 / 5=0.8$. Therefore, the mean score for each category is as follows:
A) (1 to 1.80) extremely disagree. This average represents Laggards category.
B) (1.81 to 2.60) disagree. This average represents customers the Late Majority category.
C) (2.61 to 3.40) neutral. This average represents clients The Early Majority category.
D) (3.41 to 4.20) agree. This average represents Early Adopters category.
E) (4.21 to 5) extremely agree. This average represents Innovators category. 
A total of 318 customers responded to research questionnaire with a response rate of (83\%). Those customers have been classified according to their levels of innovativeness into: innovators, early adopters, early majority, late majority, and laggards. Unlike the results of (Roger, 2005), the five categories of customer innovativeness are represented differently in mobile phone customers among the Egyptian uni versities students. Table 4 explains customer innovativeness levels in research sample.

Table 4. Customer innovativeness levels in research population

\begin{tabular}{|c|c|c|c|c|c|c|}
\hline & \multicolumn{5}{|c|}{ Customer innovativeness Level } & \multirow[b]{2}{*}{ Total } \\
\hline & Innovators & $\begin{array}{c}\text { Early } \\
\text { Adopters }\end{array}$ & $\begin{array}{c}\text { Early } \\
\text { Majority }\end{array}$ & $\begin{array}{r}\text { Late } \\
\text { majority }\end{array}$ & Laggards & \\
\hline Total & $\begin{array}{c}68 \\
0\end{array}$ & 135 & 86 & 24 & $\begin{array}{c}5 \\
0\end{array}$ & 318 \\
\hline Percentage & $\% 21$ & $\% 42$ & $\% 27$ & $\% 8$ & $\% 2$ & $\% 100$ \\
\hline
\end{tabular}

According to the demographic variables, shown in table 5 below, there were 178 male customer (56\%) and 140 female customer (44\%). Male innovators represented $26 \%$ of the research sample, whereas female innovators represented only $16 \%$. This result is consistent with other studies' results that male customer are more innovative than female customers are (Wang et al., 2008). Also, laggards' percentage in male (8\%) are higher than in female (7\%).

In addition, table 5 shows that there was 262 urban areas customers (82\%) compared to only (18\%) of rural areas customers; and innovativeness level is much higher in urban area customer compared to rural area customers.

The research sample has been classified into five categories according to income level. The first category is (less than 2000 pounds), the second category is (from 2,000 pounds to less than 4,000 pounds), the third category is (from 4,000 pounds to less than 6,000 pounds), the fourth category is (from 6000 pounds to less than 8,000 pounds), and the fifth category is (more than 8,000 pounds). The classification of the research sample according to their level of income shows that the student customers in the second category represents the majority (40\% of the sample), but represent $21 \%$ of innovator customers. Whereas only $12 \%$ of the sample are in the fifth category and they represent $31 \%$ of innovator customers.

According to university distribution, table 6 below shows Cairo University comes first where with 35\% of total respondents of the research, followed by Alexandria University with $25 \%$ of total respondents, then Mansoura University with $23 \%$, and Assiut University with $11 \%$, and finally the Suez Canal University with only $6 \%$ of total respondents.

Most innovators come from Mansoura University with $36 \%$ of total respondents, while most early adopters and early majority are from Cairo University with $48 \%$ and $35 \%$ respectively. Suez Canal University and Assiut University turn to have most of late majority and laggards with $17 \%$ and $3 \%$ respectively.

Table 5. Customer innovativeness levels according to demographic variables

\begin{tabular}{|c|c|c|c|c|c|c|c|}
\hline \multirow[b]{2}{*}{ Demographic } & \multirow[b]{2}{*}{ Variables } & \multicolumn{5}{|c|}{ Customer Innovativeness Level } & \multirow[b]{2}{*}{ Total } \\
\hline & & Innovators & $\begin{array}{c}\text { Early } \\
\text { Adopters }\end{array}$ & $\begin{array}{c}\text { Early } \\
\text { Majority }\end{array}$ & $\begin{array}{c}\text { Late } \\
\text { majority }\end{array}$ & Laggards & \\
\hline \multirow{4}{*}{ Gender } & male & 46 & 75 & 39 & 14 & 4 & 178 \\
\hline & $\%$ & $\% 26$ & $\% 42$ & $\% 22$ & $\% 8$ & $\% 2$ & $\% 100$ \\
\hline & female & 22 & 60 & 47 & 10 & 1 & 140 \\
\hline & $\%$ & $\% 16$ & $\% 43$ & $\% 33.3$ & $\% 7$ & $\% 0.7$ & $\% 100$ \\
\hline \multirow{4}{*}{ Residence } & urban & 58 & 113 & 72 & 15 & 4 & 262 \\
\hline & $\%$ & $\% 22$ & $\% 43$ & $\% 27$ & $\% 6$ & $\% 2$ & $\% 100$ \\
\hline & rural & 10 & 22 & 14 & 9 & 1 & 56 \\
\hline & $\%$ & $\% 18$ & $\% 39$ & $\% 25$ & $\% 16$ & $\% 2$ & $\% 100$ \\
\hline \multirow{10}{*}{$\begin{array}{l}\text { Income } \\
\text { Level }\end{array}$} & first & 23 & 40 & 30 & 7 & 2 & 102 \\
\hline & $\%$ & $\% 23$ & $\% 39$ & $\% 29$ & $\% 7$ & $\% 2$ & $\% 100$ \\
\hline & second & 27 & 52 & 36 & 10 & 1 & 126 \\
\hline & $\%$ & $\% 21$ & $\% 41$ & $\% 29$ & $\% 8$ & $\% 1$ & $\% 100$ \\
\hline & third & 3 & 21 & 9 & 4 & 1 & 37 \\
\hline & $\%$ & $\% 8$ & $\% 57$ & $\% 24$ & $\% 11$ & $\% 3$ & $\% 100$ \\
\hline & fourth & 3 & 9 & 2 & 0 & 0 & 14 \\
\hline & $\%$ & $\% 22$ & $\% 64$ & $\% 14$ & 0 & 0 & $\% 100$ \\
\hline & fifth & 12 & 13 & 9 & 3 & 2 & 39 \\
\hline & $\%$ & $\% 31$ & $\% 33$ & $\% 23$ & $\% 8$ & $\% 5$ & $\% 100$ \\
\hline
\end{tabular}


Table 6. Customer innovativeness levels according to university sample distribution

\begin{tabular}{ccccccc}
\hline University & \multicolumn{7}{c}{ Customer Innovativeness Level } & \multirow{2}{*}{ Total } \\
\cline { 2 - 6 } & \multirow{2}{*}{ Innovators } & $\begin{array}{c}\text { Early } \\
\text { Adopters }\end{array}$ & $\begin{array}{c}\text { Early } \\
\text { Majority }\end{array}$ & $\begin{array}{c}\text { Late } \\
\text { Majority }\end{array}$ & Laggards \\
\hline Cairo University & 10 & 53 & 38 & 7 & 2 & 110 \\
\% & $\% 9$ & $\% 48$ & $\% 35$ & $\% 6$ & $\% 2$ & $\% 100$ \\
Alexandria University & 17 & 33 & 24 & 5 & 1 & 80 \\
\% & $\% 21$ & $\% 41$ & $\% 30$ & $\% 6$ & $\% 2$ & $\% 100$ \\
Mansoura University & 27 & 31 & 10 & 5 & 1 & 74 \\
\% & $\% 36$ & $\% 42$ & $\% 14$ & $\% 7$ & $\% 1$ & $\% 100$ \\
Suez Canal University & 2 & 8 & 5 & 3 & 0 & 18 \\
\% & $\% 11$ & $\% 44$ & $\% 28$ & $\% 17$ & 0 & $\% 100$ \\
Assiut University & 12 & 10 & 9 & 4 & 1 & 36 \\
\% & $\% 33$ & $\% 28$ & $\% 25$ & $\% 11$ & $\% 3$ & $\% 100$ \\
\hline
\end{tabular}

5.2 The Research Variables Averages According to Customer Innovativeness Levels

The results has shown that the overall level of general innovativeness for all customers in the research sample is (3.50), meaning that the overall research sample fall into the early adopters category, as is evident in table 7 that all dimensions of customer innovativeness falls in this (3.41 to 4.20) except only one dimension that is the need for uniqueness dimension. This dimension falls in the early majority category (2.61 To 3.40). This result is noticed reasonably normal. The research sample have better educational level than other groups in society and they are young (average age 18 to 28 years old). So, their tendency to try new mobile devices is higher than others (Wang et al., 2008). Table 7 also has shown a correlation between the average of customer involvement, perceived risks, and new mobile phones adoption intentions from one side, and customer innovativeness levels from the other side. It is found that the greater the level of customer innovativeness, the more involved is the customer to mobile phones, the more the adoption intention, and the less is the perceived risks. The level of customer involvement decrease as customer innovativeness decrease (the customer involvement average for each innovati veness level is, $4.57,3.81,3.03,2.22$, and 1.40). In addition, it turns out that adoption intentions to new mobile phones gradually decrease with the decrease of customer innovativeness (the average adoption intentions for each innovativeness level is: $3.90,3.49,3.17,3.14$, and 2.8). In contrast, the perceived risk level increases gradually with the decrease of customer innovativeness (the average perceived risks for each innovativeness level is: $2.51,271,2.75,2.78$, and 3.4 ).

Table 7 . The research variables averages according to customer innovativeness levels

\begin{tabular}{ccccccc}
\hline Variables & $\begin{array}{c}\text { Total } \\
\text { customers } \\
(\mathrm{N}=318)\end{array}$ & $\begin{array}{c}\text { Innovators } \\
(\mathrm{N}=68)\end{array}$ & $\begin{array}{c}\text { Early } \\
\text { Adopters } \\
(\mathrm{N}=135)\end{array}$ & $\begin{array}{c}\text { Early } \\
\text { Majority } \\
(\mathrm{N}=86)\end{array}$ & $\begin{array}{c}\text { Late } \\
\text { Majority } \\
(\mathrm{N}=24)\end{array}$ & $\begin{array}{c}\text { Laggards } \\
(\mathrm{N}=5)\end{array}$ \\
\hline Need for Uniqueness & 3.18 & 3.18 & 3.21 & 2.73 & 2.91 & 2.350 \\
Need for Novelty & 3.44 & 4.08 & 3.49 & 3.05 & 2.81 & 2.86 \\
Need for Recognition & 3.61 & 4.32 & 3.63 & 3.16 & 3.17 & 3.25 \\
Need for Functional Benefit & 3.65 & 4.14 & 3.70 & 3.31 & 3.26 & 3.1 \\
Need for Decision Making & 3.63 & 3.93 & 3.64 & 3.51 & 3.43 & 3.06 \\
$\quad$ Independence & 3.50 & 4.06 & 3.54 & 3.16 & 3.14 & 2.93 \\
General Innovativeness & 3.60 & 4.57 & 3.81 & 3.03 & 2.22 & 1.40 \\
Customer Involvement & 2.70 & 2.51 & 2.71 & 2.75 & 2.78 & 3.4 \\
$\quad$ Perceived Risk & 3.45 & 3.90 & 3.49 & 3.17 & 3.14 & 2.8 \\
Adoption Intentions of New Mobile & & & & & &
\end{tabular}

5.3 Hypotheses testing

Hypotheses 1 was tested using Mann Whitney test to clarify the differences between customers perceptions of risks to new mobile phones, innovativeness, involvement, and adoption intentions according to demographic variables as shown in table 8 and 9: 
Table 8. Differences between customers perceptions of research variables according to gender and place of residence

\begin{tabular}{|c|c|c|c|c|c|c|c|c|}
\hline \multirow[b]{2}{*}{ Variables } & \multicolumn{4}{|c|}{ Gender } & \multicolumn{4}{|c|}{ Place of Residence } \\
\hline & $\begin{array}{c}\text { Males } \\
\mathrm{N}=178\end{array}$ & $\begin{array}{l}\text { Females. } \\
\mathrm{N}=140\end{array}$ & $\begin{array}{c}Z \\
\text { value }\end{array}$ & $\begin{array}{l}\text { Significance } \\
\text { level }\end{array}$ & $\begin{array}{c}\text { urban } \\
\mathrm{N}=262\end{array}$ & $\begin{array}{c}\text { rural } \\
\mathrm{N}= \\
56\end{array}$ & Zvalue & $\begin{array}{l}\text { Significance } \\
\text { level }\end{array}$ \\
\hline Need for Uniqueness & 3.25 & 3.08 & 1.57 & 0.117 & 3.40 & 3.13 & 1.81 & 0.07 \\
\hline Need for Novelty & 3.51 & 3.36 & 1.83 & 0.067 & 3.50 & 3.43 & 0.32 & 0.75 \\
\hline Need for Recognition & 3.62 & 3.60 & 0.23 & 0.816 & 3.88 & 3.55 & 2.72 & 0.006 \\
\hline Need for Functional Benefit & 3.65 & 3.65 & 0.579 & 0.563 & 3.74 & 3.63 & 0.615 & 0.54 \\
\hline $\begin{array}{l}\text { Need for Decision } \\
\text { Making Independence }\end{array}$ & 3.70 & 3.53 & 2.05 & 0.040 & 3.60 & 3.63 & 0.134 & 0.89 \\
\hline General Innovativeness & 3.55 & 3.45 & 1.63 & 0.10 & 3.62 & 3.47 & 1.60 & 0.11 \\
\hline Customer Involvement & 3.67 & 3.53 & 2.04 & 0.041 & 3.63 & 3.49 & 0.90 & 0.365 \\
\hline Perceived Risk & 2.68 & 2.72 & 0.547 & 0.58 & 2.68 & 2.76 & 0.38 & 0.70 \\
\hline $\begin{array}{l}\text { Adoption Intentions of New } \\
\text { Mobile Phones }\end{array}$ & 3.47 & 3.44 & 1.02 & 0.31 & 3.48 & 3.36 & 1.22 & 0.22 \\
\hline
\end{tabular}

Table 9. Differences between customers perceptions of research variables according to income level

\begin{tabular}{|c|c|c|c|c|c|c|c|c|}
\hline Variables & $\begin{array}{c}<2000 \\
(N= \\
102)\end{array}$ & $\begin{array}{l}2000 \\
<4000 \\
(N \\
126) \\
\end{array}$ & $\begin{array}{l}- \\
=\end{array}$ & $\begin{array}{c}4000- \\
<6000 \\
(N=37)\end{array}$ & $\begin{array}{c}6000-< \\
8000 \\
(N=14)\end{array}$ & $\begin{array}{c}>8000 \\
(N=39)\end{array}$ & $\chi^{2}$ & $\begin{array}{c}\text { Significance } \\
\text { level }\end{array}$ \\
\hline Need for Uniqueness & 3.18 & 3.25 & & 3.08 & 3.13 & 3.40 & 13.93 & 0.008 \\
\hline Need for Novelty & 3.44 & 3.51 & & 3.36 & 3.43 & 3.50 & 14.67 & 0.005 \\
\hline Need for Recognition & 3.61 & 3.62 & & 3.60 & 3.55 & 3.88 & 3.83 & 0.429 \\
\hline Need for Functional Benefit & 3.65 & 3.65 & & 3.65 & 3.63 & 3.74 & 3.33 & 0.504 \\
\hline $\begin{array}{l}\text { Need for } \\
\text { Decision Making Independence }\end{array}$ & 3.63 & 3.70 & & 3.53 & 3.63 & 3.60 & 0.585 & 0.965 \\
\hline General Innovativeness & 3.45 & 3.47 & & 3.50 & 3.55 & 3.62 & 8.96 & 0.062 \\
\hline Customer Involvement & 3.60 & 3.67 & & 3.53 & 3.63 & 3.49 & 5.76 & 0.218 \\
\hline Perceived Risk & 2.70 & 2.68 & & 2.72 & 2.68 & 2.76 & 5.07 & 0.281 \\
\hline $\begin{array}{l}\text { Adoption Intentions of New } \\
\text { Mobile Phones }\end{array}$ & 2.45 & 3.47 & & 3.44 & 3.48 & 3.36 & 3.05 & 0.550 \\
\hline
\end{tabular}

Based on the above, it can be concluded that:

1) According to gender: there is significant difference between mobile customers perceptions of the customer involvement variable only. The average involvement of male customers is larger than for female customers, (3.67 and 3.53) with (Z) value of (2.04) at 0.05 significance level. The cause of the significant differences is that males are more interested in modern technology in general and mobile phones in particular. Especially at such age and study, male students usually care about new de vices, more female customers. There is no significant differences between customers' perceptions of innovativeness variable except for perception of the Need for Decision Making Independence dimension where the average for male customer is (3.70), while the average for female customer is (3.53) and value of $(Z)$ is significant 2.05 at 0.05 level. There is no significant differences between customers' perception of the perceived risk variable, or of the adoption intention variable.

2) According to place of residence: no significant difference is found between mobile customers perceptions of customer innovativeness variable where the value of $(\mathrm{Z}) 1.60$ is non-significant at 0.11 level, except for perception of the Need for Recognition dimension where the average for urban customer is (3.88), while the average for rural customer is (3.55) and value of $(Z)$ is significant 2.72 at 0.01 level. There is no significant differences between customers' perception of the involvement variable, perceived risk variable, or the adoption intention variable

3) According to level of income: there is significant difference between mobile customers perceptions of customer innovativeness variable only, where the value (Z) 8.96 is significant at 0.05 level. Significant differences also emerged in two dimensions at 0.01 level: the need for uniqueness and the need for novelty, where the value of $(\mathrm{Z})$ were 13.93, 14.67 respectively, the level of significance of both dimensions respectively $0.008,0.005$. While there is no significant differences between customers perceptions of involvement variable, perceived risk variable, or the adoption intention variable.

The model that has been proposed to test the role of the customer innovativeness on the adoption intentions of new mobile phones was analysed for suitabilityusing Analysis of Structures Moment Tool (AMOS v22). 
Emphasis was given to six indicators: Residual Root Mean Square RMR, Goodness-of-Fit Index GFI, Incremental Fit Index IFI, Comparative Fit Index CFI, and Chi-square/degrees of freedom ( $\chi 2 / \mathrm{df})$. Results are presented in table 10. Fit indices determine how well the proposed model fits the sample data.

Table 10. Research Model Significance Test

Innovativeness/ Adoption Intentions

\begin{tabular}{cccccc}
$\boldsymbol{R M R}$ & $\boldsymbol{G F I}$ & $\boldsymbol{I F I}$ & $\boldsymbol{C F I}$ & $\chi^{2}$ & $\boldsymbol{d} \boldsymbol{f}$ \\
\hline Zero & 1. & 1. & 1. & 0.000 & 0 \\
\hline
\end{tabular}

Hypotheses 2, 3, and 4 are tested using Path analysis method. As for Hypotheses 2, it is revealed from table (7) that the level of customer involvement has a direct positive relationship with the level of customer innovativeness. From the path analysis results (table 11 below), it is shown that general customer innovativeness dimensions have a significant positive effect on customers' involvements with new mobile phones except for the need for uniqueness dimension. It can be concluded that customer innovativeness five dimensions explain $61.7 \%$ of the customers' involvements with new mobile phones.

Table 11. Path analysis: general customer innovativeness dimensions and customers' involvements

\begin{tabular}{lcccc}
\hline \multicolumn{1}{c}{ Variables } & $\boldsymbol{\beta}$ & SE & Path coefficient & significance \\
\hline General innovativeness & 0.567 & 0.06 & 0.564 & $* * *$ \\
Need for Uniqueness & 0.098 & 0.05 & 0.416 & 0.107 \\
Need for Novelty & 0.265 & 0.06 & 0.510 & $* * *$ \\
Need for Recognition & 0.156 & 0.06 & 0.476 & 0.017 \\
Need for Functional Benefit & 0.138 & 0.05 & 0.372 & 0.008 \\
Need for Decision Making Independence & 0.129 & 0.05 & 0.259 & 0.008 \\
\hline
\end{tabular}

These results are due to the fact that high initiative customers tend to involve more in new products, as they are better able to devote the effort, time and money to be different from the others.

As for Hypotheses 3, table 7 shows that the perceived risks level increase with the decrease of customer innovativeness level. However, from the path analysis results (Table 12), it is shown that only two of customer innovativeness dimensions have a significant negative effect on customers' perceived risks towards mobile phones, namely: the need for uniqueness and the need for decision making independence. While the other three dimensions (the need for novelty, the need for recognition, and the need for functional benefit) do not have a significant negative effect on customers' perceived risks. It is concluded that customer innovativeness dimensions explain $51.1 \%$ of the customers' perceived risks towards mobile phones.

Table 12. Path analysis: general customer innovativeness dimensions and customers' perceived risks

\begin{tabular}{lcccc}
\hline \multicolumn{1}{c}{ Variables } & $\boldsymbol{\beta}$ & SE & Path coefficient & Significance \\
\hline General innovativeness & -0.265 & 0.066 & -0.265 & $* * *$ \\
Need for Uniqueness & -0.180 & 0.054 & -0.238 & 0.010 \\
Need for Novelty & 0.018 & 0.072 & -0.171 & 0.818 \\
Need for Recognition & -0.012 & 0.067 & 0.183. & 0.877 \\
Need for Functional Benefit & -0.098 & 0.054 & -0.190 & 0.104 \\
Need for Decision Making Independence & -0.167 & 0.058 & -0.220 & 0.003 \\
\hline
\end{tabular}

A possible reason for such results is the fact that high initiative customers differ from others in many economic and social characteristics (education, social status), communication behaviours (social participation, knowledge innovation, continuous exposure to various media), as well as personal characteristics (desire to change, self-confidence). They are less sensitive to threats, which maximise the tendency to accept the risks.

As for Hypotheses 4, table 7 shows that the customers intentions to adopt new mobile phones increase with the increase of customer innovativeness level. However, from the path analysis results (Table 13), it is shown that only two of customer innovativeness dimensions have a significant positive effect on customers' adoption intentions, namely: the need for functional benefit and the need for uniqueness. While the other three dimensions (the need for novelty, the need for recognition, and the need for decision making independence) do not have a significant positive effect on customers' adoption intentions. It is concluded that customer innovativeness dimensions explain $51.1 \%$ of the customers' perceived risks towards mobile phones.

Table 13. Path analysis: general customer innovativeness dimensions and customers' adoption intentions

\begin{tabular}{lcccc}
\hline \multicolumn{1}{c}{ Variables } & $\boldsymbol{\beta}$ & SE & Path coefficient & Significance \\
\hline General innovativeness & 0.376 & 0.077 & 0.505 & $* * *$ \\
Need for Uniqueness & 0.175 & 0.046 & 0.427 & 0.005 \\
Need for Novelty & 0.065 & 0.061 & 0.422 & 0.362 \\
Need for Recognition & 0.068 & 0.056 & 0.406 & 0.310 \\
Need for Functional Benefit & 0.201 & 0.046 & 0.411 & $* * *$ \\
Need for Decision Making Independence & 0.060 & 0.050 & 0.230 & 0.229 \\
\hline
\end{tabular}




\section{Conclusions and Contributions}

Generally, the previous section determines a set of results that can summarise the role of customer innovativeness in new products adoption intentions. The conclusions of the research deepen the comprehension of customers' perception of modern concepts regarding the adoption experience. In view of that, a set of recommendations are put forward to optimise the use of the results. First, marketing managers at Egyptian organizations should clearly identify customer groups in society according to the level of innovativeness. This should help to identify the target market easily, and consequently, succeed in the new product diffusion and adoption. Second, the research finds $21 \%$ of the sample as innovative customers, in contrast with only $2.5 \%$ innovative customers in the society=ty in general. Hence, particular attention should be paid to young people generally, and university students particularly when introducing a new product to the market, as their innovativeness are higher than other groups' in the society. Third, marketing managers need to work to reduce the risks perceived by customers by providing sufficient guarantees and customer service when purchasing a new product such as maintenance services. Also they need to increase customer new product involvement, through expanded promotions for the new product to grab their attention. Fourth, focus must be placed on functional benefits when introducing a new product, more than other benefits, as the research proved that functional benefit is the main reason to adopt new mobile phones, followed by customer's need for uniqueness.

Some limitation of this research should be acknowledged. The major limitation is spatial. Data collection of this research has been confined to only five governmental universities, by selecting the major university in every main region of the Arab Republic of Egypt. Another limitation is that the research sample was limited to public universities students. Private universities students were excluded from the sample. Also, the research proposed the innovativeness-adoption model applied on a tangible product.

Future researches can consider applying the model on services and identify the nature of the relationships between the research variables in the service sector. Also, it might be interesting applying the same model on other age segments, and/ or other functional segments. Finally, as this research is studying the role of customer innovativeness in developing adoption intentions, it could be significant if a future researches examine the role of customer innovativeness in adoption behaviour for new products.

\section{References}

Agarwal, S., \& Teas, R. K. (2001). Perceived Value: Mediating Role of Perceived Risk. Journal of Marketing Theory and Practice, 9(4), 1-14. https://doi.org/10.1080/10696679.2001.11501899

Alsaleh, D. A. (2010). A Social model for the consumer acceptance of technology innovation, PhD Dissertation, University Carbondale.

Bartels, J., \& Machiel, J. R. (2011). Consumer innovativeness and its correlates: A propositional inventory for future research. Journal of Business Research, 64(6), 601-609. https://doi.org/10.1016/j.jbusres.2010.05.002

Beneke, J., Greene, A., Lok, I., \& Mallett, K. (2012). The influence of perceived risk on purchase intent: the case of premium grocery private label brands in South Africa. Journal of Product \& Brand Management, 21(1), 4-14. https://doi.org/10.1108/10610421211203060

Bhukya, R., \& Sapna, S. (2015). The effect of perceived risk dimensions on purchase intention: An empirical evidence from Indian private labels market. American Journal of Business, 30(4), 218-230. https://doi.org/10.1108/AJB-10-2014-0055

Carroll, M. S. (2009). Development of a scale to measure perceived risk in collegiate spectator sport and assess its impact on sport consumption intentions. PhD dissertation, University of Florida.

Chao, C. W., \& Mike, R. (2010). Consumer Innovativeness and Chinese' Really New Product Adoption Behaviour. The Australian and New Zealand Marketing Academy (ANZMAC), 2010 .

Chau, P., \& Hu, P. (2001). Information Technology Acceptance by Individual Professionals: A Model of Comparison Approach. Decision Sciences, 32(4), 699-719.

https://doi.org/10.1111/j.1540-5915.2001.tb00978.x

Choubtarash, N., Mahdieh, O., \& Marnani, A. (2013). The study of the relationship between consumer involvement and purchase decision (Case study: Cell phone). Interdisciplinary Journal of Contemporary Research in Business, 4(12), 276-296.

Dholakia, U. M. (2001). A motivational process model of product involvement and consumer risk perception. European Journal of Marketing, 35(11/12), 1340-1362. https://doi.org/10.1108/EUM0000000006479 
Dobre, C., Anca, D., \& Gheorghe, P. (2009). Consumer Innovativeness: A Marketing Approach. Management and Marketing, 4(2), 19-34.

Fowler, K., \& Eileen B. (2010). Consumer innovativeness: Impact on expectations, perceptions, and choice among retail formats. Journal of Retailing and Consumer Services, 17, 492-500. https://doi.org/10.1016/j.jretconser.2010.08.004

Ghafelehbashi, S., Amin, A., \& Fatemeh, N. (2011). Acquaintance with All Types of Involvement in Consumer Behavior. Interdisciplinary Journal of Contemporary Research in Business 3(5).

Goldsmith, R. E., \& Hofacker C. F. (1991). Measuring Consumer Innovativeness. Journal of the Academy of Marketing Science, 19(3), 209-221. https://doi.org/10.1007/BF02726497

Hair Jr, Joseph, F., Black, W. C., Babin, B. J., Anderson, R. E., \& Tatham, R. L. (2006). Multivariate Data Analysis. Auflage, Upper Saddle River.

Handa, M., \& Gupta, N. (2009). Gender Influence on the Innovativeness of Young Urban Indian Online Shoppers. The Journal of Business Perspective, 13(2), 25-32. https://doi.org/10.1177/097226290901300203

Hanzaee, K. H., Mahsa, K., \& Afshin, R. (2011). Evaluation of the effects of product involvement facets on brand loyalty. African Journal of Business Management, 5(16), 6964-6971.

Hanzaee, K. H., Mina, M. A., \& Fatemeh, A. (2010). Investigating the Effect of Gender Role Attitude on the Relationship Between Dimensions of Religiosity and New Product Adoption Intention. World Applied Sciences Journal, 13(6), 1527-1536.

Hoffmann, S., \& Katja, S. (2010). A cognitive model to predict domain-specific consumer innovativeness. Journal of Business Research, 63, 778-785. https://doi.org/10.1016/j.jbusres.2009.06.007

Huang, C. Y., Chia-Jung, C., \& Pei-Ching, L. (2010). Involvement theory in constructing bloggers' intention to purchase travel products. Tourism Management, 31, 513-526. https://doi.org/10.1016/j.tourman.2009.06.003

Huang, L. Y., Ying, J. H., \& Shuchih, E. C.(2011). The effect of consumer innovativeness on adoption of location-based services. Review of Global Management and Service Science, 1, 17-31

Im, S., Mason, C. H., \& Houston, M. B. (2007). Does Innate Consumer Innovativeness Related to New Product/Service Adoption Behavior? The Intervening Role of Social Learning via Vicarious Innovativeness. Journal of Academy Marketing Science, 35(1), 63-75. https://doi.org/10.1007/s11747-006-0007-z

Jordaan, Y., \& Simpson, M. N. (2006). Consumer innovati veness among females in specific fashion stores in the Menlyn shopping centre. Journal of Family Ecology and Consumer Sciences, 34(1).

Kim, H. L. (2003). A study of perceived risk on airline tickets purchasing intention, Master dissertation, Faculty of the Graduate College of the Oklahoma State University.

Kim, Y. H. (2008). An empirical examination of consumers innovation, fashion orientation and utilitarian and hedonic consumer attitudes, Master dissertation, The University of North Carolina at Greensboro research

Klerck, D., \& Sweeney, J. C. (2007). The effect of knowledge types on consumer perceived risk and adoption of genetically modified foods. Psychology \& Marketing, 24(2), 171-193. https://doi.org/10.1002/mar.20157

Klink, R. R., \& Athaide, G. A. (2010). Consumer Innovativeness and the Use of New versus Extended Brand Names for New Products. Journal of Product Innovation Management, 27(1), 23-32. https://doi.org/10.1111/j.1540-5885.2009.00697.x

Knight, D. K., \& Eun Y. (2007). Japanese consumers' need for uniqueness Effects on brand perceptions and purchase intention. Journal of Fashion Marketing and Management, 11(2), 270-280. https://doi.org/10.1108/13612020710751428

Lee, S. (2005). The influence of product involvement and fan identification on response to team sponsors' products, $\mathrm{PhD}$ dissertation, The Ohio State University.

Leon, G. S., Kanuk, L. L., \& Ramesh, S. K. (2004). Consumer behaviour.

Lin, L. Y., \& Chun, S. C. (2006). The influences of the country-of-origin image, product knowledge, product involvement on consumer purchase decisions: an empirical study of insurance and catering services in Taiwan. Journal of Consumer Marketing, 23(5), 248-265. https://doi.org/10.1108/07363760610681655

Michaelidou, N., \& Dibb, S. (2008). Consumer involvement: a new perspective. Marketing Review, 8(1), 83-99. 
https://doi.org/10.1362/146934708X290403

Rogers, E. (2003). Diffusion of Innovations. (5th ed.). New York

Shimp, T. A. (2000). Advertising promotion. Supplemental Aspects of Integrated.

Slovic, P., \& Weber, E. U. (2002). Perception of risk posed by extreme events, Paper presented at the Risk Management Strategies in an Uncertain World Conference, Palisades, NY.

Ueltschy, B., Krampf, R. F., \& Yannopoulos, P. (2004). A Cross-National Study of Perceived Consumer Risk Towards Online (Internet) Purchasing. The Multinational Business Review, 12(2), 59-82 . https://doi.org/10.1108/1525383X200400010

Vandecasteele, B., \& Maggie G. (2010). Motivated Consumer Innovativeness: Concept, measurement, and validation. Intern. J. of Research in Marketing, 27, 308-318. https://doi.org/10.1016/j.ijresmar.2010.08.004

Vandecasteele, B., \& Maggie, G. (2009). Revising the myth of gay consumer innovativeness. Journal of Business Research, 62(1), 134-144. https://doi.org/10.1016/j.jbusres.2008.01.005

Wang, G., Weny, D., \& Nan, Z. (2008). Consumption attitudes and adoption of new consumer products: a contingency approach. European Journal of Marketing, 42(1/2), 238-254. https://doi.org/10.1108/03090560810840998

Ward, S. J. (2008). The consumer-perceived risk associated with the intention to purchase online. Master dissertation, the Department of Business Management at Stellenbosch University.

Wilke, J., \& Sorvillo, N. (2003), "Targeting early adopters: a means for new product survival. Consumer Insights, $5(1), 15-27$.

Xu, J., Chen, Z., \& He, Y. (2003). Efficient Fast ME Predictions and Early-termination Strategy Based on H. 264 Statistical Characters.

Zielke, S., \& Dobbelstein, T. (2007). Customers' willingness to purchase new store brands. Journal of Product \& Brand Management, 16(2), 112-121. https://doi.org/10.1108/10610420710739982

\section{Copyrights}

Copyright for this article is retained by the author(s), with first publication rights granted to the journal.

This is an open-access article distributed under the terms and conditions of the Creative Commons Attribution license (http://creativecommons.org/licenses/by/4.0/). 